\title{
Revisiting an Old Issue: The Discrepancy Between Tissue Ratio-Derived Binding Parameters and Kinetic Modeling-Derived Parameters After a Bolus of the Serotonin Transporter Radioligand ${ }^{123}$ I-ADAM
}

$\mathbf{I}_{\mathrm{n}}$ search based on radiolabeled pro has been performed in 2 imaging modalities-PET and SPECT. It is generally agreed that PET is the more quantitatively precise of the two (l) for a variety of reasons, such as the ease with which accurate attenuation correction can be implemented, or the better spatial resolution of PET in commercially produced scanners. Additionally, the fact that there are

\section{See page 247}

positron-emitting isotopes of small atoms, especially ${ }^{11} \mathrm{C}$, has led to a large number of PET probes with affinity for numerous targets. But the short half-life of ${ }^{11} \mathrm{C}$ is also the source of one of the main limitations of PET: ${ }^{11} \mathrm{C}$-labeled radioligands require onsite cyclotrons and local expertise in radioligand synthesis. This limitation generally restricts brain PET research to large academic institutions capable of supporting these instruments and staff. The longer half-lives of SPECT isotopes make it possible to conduct brain imaging research at institutes that do

Received Oct. 2, 2007; revision accepted Oct. 22, 2007.

For correspondence or reprints contact: Mark Slifstein, PhD, Columbia University and New York State Psychiatric Institute, 1051 Riverside Dr., Unit 31, New York, NY 10032.

E-mail: mms218@columbia.edu

COPYRIGHT (C) 2008 by the Society of Nuclear Medicine, Inc.

DOI: 10.2967/jnumed.107.046631 not have the infrastructural support for research PET, potentially gaining access to clinical populations that may not otherwise be included in imaging research. Thus there is a continued role for SPECT in imaging research, and there are target molecules that are studied with both modalities.

The serotonin reuptake transporter is one such target molecule of great interest in PET and SPECT neuroimaging. Because of its localization on serotonergic nerve terminals, serotonin transporter binding has been interpreted as a marker for the density and integrity of the serotonin system. Imaging studies have been used to investigate serotonin transporter in mood disorders $(2,3)$, obsessive-compulsive disorder $(4,5)$, alcohol dependence (6), and substance abuse $(7,8)$. Early studies were performed using ${ }^{123} \mathrm{I}-2 \beta$ carbomethoxy-3 $\beta$-(4-iodophenyl)tropane ( ${ }^{123}$ I- $\beta$-CIT) $(9)$, the only imaging agent available at the time. But ${ }^{123} \mathrm{I}-\beta$ CIT has similar affinity for dopamine transporters and serotonin transporter (10) and so cannot unambiguously image serotonin transporter in regions where both proteins are abundant. This is especially so in the striatum, where serotonin transporter density is high, but dopamine transporter density is an order of magnitude higher; ${ }^{123} \mathrm{I}-\beta$-CIT is used to image dopamine transporters in striatum. Eventually, several additional ligands that are much more highly selective for serotonin transporters became available for imaging humans, including trans-1,2,3,5,6,10- $\beta$-hexahydro 6-[4-(methylthio)phenyl]pyrrolo-[2,1-a]isoquinoline $\left({ }^{11} \mathrm{C}-\mathrm{McNeil}\right.$ 5652) (11) and ${ }^{11} \mathrm{C}-\mathrm{N}, \mathrm{N}$-dimethyl-2-(2-amino-4cyanophenylthio)-benzylamine $\left({ }^{11} \mathrm{C}\right.$ DASB) (12) for PET and ${ }^{123}$ I-labeled 2-((2-((dimethylamino)methyl)phenyl)thio)-5-iodophenylamine ( ${ }^{123} \mathrm{I}-$ ADAM) (13) for SPECT. To date, there are more than 30 published ${ }^{123} \mathrm{I}$ ADAM studies; at least 12 of these were performed on humans.

The underlying pharmacokinetic theory that has led, over the past 2 decades, to the development of robust models for the extraction of parameter estimates from imaging experiments applies equally to PET and SPECT data. But these modeling approaches have been adapted more wholeheartedly in the PET rather than the SPECT literature, where data analysis frequently consists of measuring concentration ratios between receptor-rich regions and reference regions devoid of receptors during some fixed interval after tracer injection. In particular, several published ${ }^{123}$ I-ADAM studies on humans have used ratio methods for data analysis. These ratios, however, truly represent the desired parameter (binding potential relative to the nondisplaceable component of the brain signal $\left[\mathrm{BP}_{\mathrm{ND}}\right]$ ) only under steady-state conditions and not when concentrations are changing with time, as is the case after a bolus injection of this radioligand. In this issue of The Journal of Nuclear Medicine, Frokjaer et al. (14) remind us of the foibles of this approach. These authors have acquired 
${ }^{123}$ I-ADAM data for human subjects and have compared several simplified approaches for data analysis - reference region methods (simplified (15) and graphical (16)) and the ratio methodwith full kinetic modeling using arterial plasma samples as an input function. They have demonstrated that tissue ratios, taken late in the scan, greatly overestimate $\mathrm{BP}_{\mathrm{ND}}$ relative to the plasmabased approach, whereas the other methods do not. This is not a new issue in the brain imaging literature. It was explored in depth by Carson et al. (17) but is a discussion worth repeating.

Intuitively, late in an experiment after a bolus injection of radioligand, the concentration in the reference region will approach its equilibrium value, relative to the low plasma levels of radioligand, more rapidly than will the concentration in a receptor-rich region, because of the comparatively slow rate of dissociation of receptorbound ligand. This phenomenon has been described in mathematic detail (17); a brief mathematic exposition is given below for a simple special case of practical relevance. This phenomenon would be of little consequence if it led to a uniform bias across subjectsresearchers are generally more interested in comparisons across conditions or populations than in the absolute quantification of $\mathrm{BP}_{\mathrm{ND}}$. However, the magnitude of the effect will depend on the peripheral clearance of the radioligand. How far the ratio-based estimate of $\mathrm{BP}_{\mathrm{ND}}$ varies from the true value will be a function of the relative distances of the receptor-rich region and reference region concentrations from their equilibrium values relative to the plasma levels at the time of measurement, and these in turn will be functions of the rate at which the radioligand clears from the plasma. Pathologic states or experimental manipulations that are associated with clearance differences between studied groups could potentially lead to measured differences that would be misinterpreted as authentic differences in $\mathrm{BP}_{\mathrm{ND}}$.

In their article, Frokjaer et al. make recommendations on the relative accuracy and robustness of the graphical and simplified reference tissue model approaches; they favor the graphical method. In the future, other authors may test these and perhaps some of the many published variants and refinements (18-21) with ${ }^{123}$ I-ADAM. They may or may not arrive at the same conclusions; modeling specialists have long debated the fine points of the various techniques and will no doubt continue to do so. But the bigger picture is that all these methods are based on pharmacokinetic models that account for the relationship between arterial plasma concentration and brain concentration and lead to binding parameter estimates that are independent of peripheral clearance, whereas the ratio approach, when applied during conditions other than steady state, does not.

In the following mathematic explanation for a special simple case, assume that concentrations in the receptor-rich region $\left(\mathrm{C}_{\mathrm{T}}\right)$ and in the reference region $\left(C_{R}\right)$ are well described by a "1-tissuecompartment model"; this is the case for many serotonin transporter ligands, including ${ }^{123}$ I-ADAM as demonstrated by Frokjaer et al. Then the 2 brain regions satisfy the differential equations

$$
\begin{aligned}
\frac{\mathrm{d} C_{R}}{d t} & =K_{1} C_{P}-k_{2} C_{R} \\
\frac{d C_{T}}{d t} & =K_{1} C_{P}-k_{2 a} C_{T}
\end{aligned}
$$

Eq. 1

where $C_{P}$ is the plasma concentration, and the delivery constant $\mathrm{K}_{1}$ is taken as equal across regions for notational and analytic simplicity. The constants $\mathrm{k}_{2}$ and $\mathrm{k}_{2 \mathrm{a}}$ are the rate constants for efflux from brain. In general, $\mathrm{k}_{2 \mathrm{a}}$ is less than $\mathrm{k}_{2}$; that is, efflux from the receptorrich region is slower than from the reference region because of dissociation from the receptor pool. At equilibrium, the left side of each equation equals 0 , and the concentrations satisfy the relationships

$$
\begin{aligned}
\mathrm{C}_{\mathrm{T}} & =\frac{\mathrm{K}_{1}}{\mathrm{k}_{2 \mathrm{a}}} \mathrm{C}_{\mathrm{P}}=\mathrm{V}_{\mathrm{T}} \mathrm{C}_{\mathrm{P}} \\
\mathrm{C}_{\mathrm{R}} & =\frac{\mathrm{K}_{1}}{\mathrm{k}_{2}} \mathrm{C}_{\mathrm{P}}=\mathrm{V}_{\mathrm{ND}} \mathrm{C}_{\mathrm{P}}
\end{aligned}
$$

Eq. 2 Carson et al (17)).

where $\mathrm{V}_{\mathrm{T}}$ (total distribution volume) and $\mathrm{V}_{\mathrm{ND}}$ (nondisplaceable distribution volume) are the distribution volumes of $C_{T}$ and $C_{R}$. BP $P_{N D}$, estimated from tissue ratios (measured at equilibrium), is then given by the following (22):

$$
\mathrm{BP}_{\mathrm{ND}}=\frac{\mathrm{C}_{\mathrm{T}}}{\mathrm{C}_{\mathrm{R}}}-1=\frac{\mathrm{V}_{\mathrm{T}}}{\mathrm{V}_{\mathrm{ND}}}-1 . \quad \text { Eq. } 3
$$

When the brain concentrations are not at steady state, however, the left sides of Equation 1 are not zero. In the late, washout, phase of the experiment, both are negatively valued functions of time, because the concentrations are decreasing. In this case, rearrangement of Equation 1 and substitution into Equation 3 leads to

$$
\frac{\mathrm{C}_{\mathrm{T}}}{\mathrm{C}_{\mathrm{R}}}-1=\frac{\mathrm{V}_{\mathrm{T}}}{\mathrm{V}_{\mathrm{ND}}}\left(\frac{\mathrm{K}_{1} \mathrm{C}_{\mathrm{P}}+\left|\mathrm{dC}_{\mathrm{T}} / \mathrm{dt}\right|}{\mathrm{K}_{1} \mathrm{C}_{\mathrm{P}}+\left|\mathrm{d} \mathrm{C}_{\mathrm{R}} / \mathrm{dt}\right|}\right)-1 .
$$

Because both derivatives are negative, both $C_{T}$ and $C_{R}$ will exceed their respective equilibrium values relative to $\mathrm{C}_{\mathrm{P}}$. The magnitude of $\mathrm{BP}_{\mathrm{ND}}$ estimated from tissue ratios during this phase, relative to the true $\mathrm{BP}_{\mathrm{ND}}$, will be determined by the relative magnitudes of $\left|\mathrm{dC}_{\mathrm{T}} / \mathrm{dt}\right|$ and $\left|\mathrm{dC}_{\mathrm{R}} / \mathrm{dt}\right|$. Because $\mathrm{C}_{\mathrm{R}}$ will equilibrate with $C_{P}$ more rapidly than $\mathrm{C}_{\mathrm{T}}$ does, eventually $\left|\mathrm{dC}_{\mathrm{T}} / \mathrm{dt}\right|$ is greater than $\left|\mathrm{dC}_{\mathrm{R}} / \mathrm{dt}\right|$, that is, $\mathrm{C}_{\mathrm{R}}$ is "flatter" than $\mathrm{C}_{\mathrm{T}}$ late in the scan (Fig. 1 in Frokjaer et al.), and apparent $\mathrm{BP}_{\mathrm{ND}}$ will exceed true $\mathrm{BP}_{\mathrm{ND}}$. The particularly straightforward form of Equation 4 follows from the simplifying assumption of equal $\mathrm{K}_{1}$ across regions, but the same principle applies as well when delivery is not equal across regions, although the exact turning point when estimated $\mathrm{BP}_{\mathrm{ND}}$ switches from less than true $\mathrm{BP}_{\mathrm{ND}}$ to greater than true $\mathrm{BP}_{\mathrm{ND}}$ may be different. Note that even when the ratio $C_{T} / C_{R}$ is nearly constant (sometimes called pseudo or secular equilibrium), say $C_{T}=\beta C_{R}$, for some $\beta>1, \mathrm{dC}_{\mathrm{T}} / \mathrm{dt}=\beta \mathrm{dC}_{\mathrm{R}} / \mathrm{dt}$ so that apparent $\mathrm{BP}_{\mathrm{ND}}$ still exceeds true $\mathrm{BP}_{\mathrm{ND}}$. This phenomenon is clearly demonstrated in Figure 3 in the Frokjaer et al. report (and is also shown in Fig. 4 of Carson et al (17))

Mark Slifstein
Columbia University and New York State
Psychiatric Institute
New York, New York




\section{REFERENCES}

1. Ollinger JM, Fessler JA. Positron-emission tomography. IEEE Signal Process Mag. 1997;14:43-55.

2. Ichimiya T, Suhara T, Sudo Y, et al. Serotonin transporter binding in patients with mood disorders: a PET study with [C-11](+)McN5652. Biol Psychiatry. 2002;51:715-722.

3. Parsey RV, Hastings RS, Oquendo MA, et al. Lower serotonin transporter binding potential in the human brain during major depressive episodes. Am J Psychiatry. 2006;163:52-58.

4. Hesse S, Mulller U, Lincke T, et al. Serotonin and dopamine transporter imaging in patients with obsessive-compulsive disorder. Psychiatry Res Neuroimaging. 2005;140:63-72.

5. Simpson HB, Lombardo I, Slifstein M, et al. Serotonin transporters in obsessive compulsive disorder: a positron emission tomography study with $\left[{ }^{11} \mathrm{C}\right] \mathrm{McN}$ 5652. Biol Psychiatry. 2003;54: 1414-1421.

6. Heinz A, Jones DW, Gorey JG, et al. Serotonin transporter availability correlates with alcohol intake in non-human primates. Mol Psychiatry. 2003;8:231-234.

7. Buchert R, Thomasius R, Nebeling B, et al. Longterm effects of "ecstasy" use on serotonin transporters of the brain investigated by PET. $J$ Nucl Med. 2003;44:375-384.

8. McCann UD, Szabo Z, Seckin E, et al. Quantitative PET studies of the serotonin transporter in MDMA users and controls using [C-11]McN5652 and [C-11]DASB. Neuropsychopharmacology. 2005; 30:1741-1750.

9. Neumeyer JL, Wang S, Milius RA, et al. $\left[{ }^{123} I\right] 2 \beta$ carbomethoxy-3 $\beta$-(4-iodophenyl)tropane $(\beta-\mathrm{CIT})$ : high affinity SPECT radiotracer of monoamine reuptake sites in brain. J Med Chem. 1991;34:3144 3146.

10. Laruelle M, Baldwin RM, Malison RT, et al. SPECT imaging of dopamine and serotonin transporters with $\left[{ }^{123} \mathrm{I}\right] \beta$-CIT: pharmacological characterization of brain uptake in nonhuman primates. Synapse. 1993;13:295-309.

11. Suehiro M, Scheffel U, Dannals RF, Ravert HT, Ricaurte GA, Wagner H Jr. A PET radiotracer for studying serotonin uptake sites: carbon-11-McN5652Z. J Nucl Med. 1993;34:120-127.

12. Houle S, Ginovart N, Hussey D, Meyer JH, Wilson AA. Imaging the serotonin transporter with positron emission tomography: initial human studies with [C-11]DAPP and [C-11]DASB. Eur J Nucl Med. 2000;27:1719-1722.

13. Oya S, Choi SR, Hou C, et al. 2-((2-((Dimethylamino)methyl)phenyl)thio-5-iodophenylamine (ADAM): an improved serotonin transporter ligand. Nucl Med Biol. 2000;27:249-254.

14. Frokjaer VG, Pinborg LH, Madsen J, et al. Evaluation of the serotonin transporter ligand ${ }^{123}$ I-ADAM for SPECT studies on humans. $J$ Nucl Med. 2008;49:247-254.

15. Lammertsma AA, Hume SP. Simplified reference tissue model for PET receptor studies. Neuroimage. 1996;4:153-158.
16. Logan J, Fowler JS, Volkow ND, Wang GJ, Ding YS, Alexoff DL. Distribution volume ratios without blood sampling from graphical analysis of PET data. J Cereb Blood Flow Metab. 1996; 16:834-840.

17. Carson RE, Channing MA, Blasberg RG, et al. Comparison of bolus and infusion methods for receptor quantitation: application to $\left[{ }^{18} \mathrm{~F}\right]$ cyclofoxy and positron emission tomography. J Cereb Blood Flow Metab. 1993;13:24-42.

18. Gunn RN, Lammertsma AA, Hume SP, Cunningham VJ. Parametric imaging of ligand-receptor binding in PET using a simplified reference region model. Neuroimage. 1997;6:279-287.

19. Ichise M, Liow JS, Lu JQ, et al. Linearized reference tissue parametric imaging methods: application to [C-11]DASB positron emission tomography studies of the serotonin transporter in human brain. J Cereb Blood Flow Metab. 2003;23:1096-1112.

20. Wu Y, Carson RE. Noise reduction in the simplified reference tissue model for neuroreceptor functional imaging. J Cereb Blood Flow Metab. 2002;22:1440-1452.

21. Zhou Y, Endres CJ, Brasic JR, Huang SC, Wong DF. Linear regression with spatial constraint to generate parametric images of ligand-receptor dynamic PET studies with a simplified reference tissue model. Neuroimage. 2003;18:975-989.

22. Innis RB, Cunningham VJ, Delforge $J$, et al. Consensus nomenclature for in vivo imaging of reversibly binding radioligands. J Cereb Blood Flow Metab. 2007;27:1533-1539. 